\title{
Feed-in-tariffs - an Australian case study
}

\author{
Nithya Saiprasad $^{1 *}$, Akhtar Kalam², Aladin Zayegh ${ }^{1}$ \\ ${ }^{1}$ College of Engineering \& Science, Victoria University, Melbourne, VIC 3011, Australia \\ ${ }^{2}$ Smart Energy Research Unit, College of Engineering and Science, Victoria University, Melbourne, VIC 3011, Australia
}

Corresponding Author Email: nithya.saiprasad@live.vu.edu.au

https://doi.org/10.18280/mmc_d.390103

Received: 10 December 2017

Accepted: 5 April 2018

\section{Keywords:}

feed-in-tariff, renewable energy, economics, renewable energy target

\begin{abstract}
Australia has been striving hard to meet the Renewable energy Target (RET). Every state in Australia has been contributing to meet RET. The Australian government has introduced energy policies to aid the adaption of renewable energy, including feed in tariffs (FiTs). The impact of FiTs in the renewable energy economics for an Australian scenario has been analyzed in this study. A university set up has been considered and the economics for optimally sized renewable energy resources is examined. In this paper the economic impact for the consumers on adapting grid connected renewable energy sources and the effect of FiTs has been analysed for the university building. The advantages and disadvantages have been scrutinized and suggestions for further improvements in FiTs for Australian scenario has been suggested.
\end{abstract}

\section{INTRODUCTION}

Global population explosion has a direct impact on the energy deficit. While most of the energy in the world is met through fossil fuels, attention has focused on renewable energy in recent years [1]. Renewable energy has taken a new dimension globally to address the global warming issue. Most of the countries around the world have put forth their share of renewable energy by exploring its available resources. Australia is one of the players in this race. Other countries like USA, China, Germany, Portugal, Spain, India etc. are also working on renewable energy adaption by executing various plans through their energy policies scheme [2]. The services provided in such schemes include discounts and rebates for the customers and thus promoting the renewable energy acquisition. The government of such countries have come up with a plan in the form of Renewable energy target (RET), by setting up a roadmap through Renewable energy policies either by materialising the new strategic plan by revising the existing Renewable energy policies or introducing a new set of policies. The country's RET is met with the help of its individual state or local Governments. Australia is working to similar criteria. In this regard, the Government of Australia has introduced various schemes and policies including Clean Energy Innovation Fund, Renewable Energy Power Percentage, Renewable Energy Certificates, Feed-in-Tariffs (FiTs), Australian Renewable Energy Agency (ARENA) etc. [3]. This paper largely focuses on Australia's RET and the FiTs introduced by the government authorities to aid in achieving country's RET. In this regard, this study focuses on understanding the advantage of FiTs for Renewable Energy adaption.

FiTs in general has provided incentives for renewable energy integration to the grid. The availability of the Renewable Energy Sources (RES) has become competitive such that FiTs have been tailored to assist in easier RE deployment [4]. The Government bodies fix the tariff price often, and the revenue is generated for every $\mathrm{kWh}$ of energy which is being "fed" into the grid. There are more than 75 countries using FiTs as the support to exploit renewable energy [5]. Typically, FiTs are fixed according to the technology and are revised in a timely manner by the government's organisation. Studies suggest that FiTs act as a booster for renewable energy (RE) technologies to evolve over time [6]. To embrace this technological evolution with economical ease, FiTs act as a catalyst between the manufacturer and consumer. Meanwhile, some studies also suggest that FiTs could have a negative impact on the RE market [1, 7]. Though FiTs help in maturity of the RE technology, one of the greatest threats it could face would be that the guaranteed returns the customer earns may lead to less competition amongst and diminish the technological growth. This could lead to lower capital costs of the RES, which could result in lower rebates on RES.

Australian wholesale electricity market known as the National Electricity Market (NEM) is a major contributor to Australia's total green-house gas (GHG) emissions, accounting for up to one-third of total emissions. This is because it heavily relies on coal to produce electricity. The coal used is of bituminous and lignite variety which are very heavy emitters of GHG. This makes Australia one of the highest per capita GHG emitters. Thus, to make a significant contribution to reducing emissions, the entire energy sector must decline to zero net emissions by 2050 [8, 9]. Complementing this fact, Australian energy consumption and GHG emission trend has put forward an increase to $14 \%$ by 2020 in university buildings (compared to other commercial buildings); their GHG emissions from such university buildings will rank second compared to other buildings and hospitals [10]. This major contribution of GHG emissions from such buildings can be minimized by implementing RES for energy production using solar, wind, hydrogen fuel cells etc.

In 2016, Australia's contribution from RES expanded due 
to the hydro energy sector making a greater contribution setting a remarkable come-back in energy sector contributing about $26 \%$ of energy. This was due to the good rainfall Australia witnessed in 2016. Approximately $17.3 \%$ of Australia's energy was from Renewables, with a powerful increase of $14.6 \%$ compared to the previous year. With the consistent downfall of solar panels and wind turbine prices since the last decade, adapting RE in Australia has improved. A maturity in the energy storage sector has been observed. In 2016, 6750 batteries of $52 \mathrm{MWh}$ capacity were installed [11]. Thus, there is a bigger drive for more renewable energy implementation in Australia. Nearly 264.1MW solar projects have been completed in 2016. With significant focus on renewable energy development, Australia needs significant support in terms of renewable energy policy until it reaches its RET. This study would act as an example to understand the impact FiT could create for the renewable energy customers.

Figure 1 shows the renewable energy penetration state-wise as of 2016 .Tasmania contributes a maximum of $93 \%$ of energy mostly from hydro energy. SA contributes $48 \%$ of renewable energy, which could be due to the fact of higher RE availability. There are $16 \%, 13 \%$ and $12 \%$ renewable energy contributions from Victoria, NSW and WA respectively. Queensland contributes least of RE of up to $5 \%$. These numbers suggest that there is more opportunity to explore RE at these locations, however these states lack the drive and support for the RE implementation as these states are bestowed with excess RE.

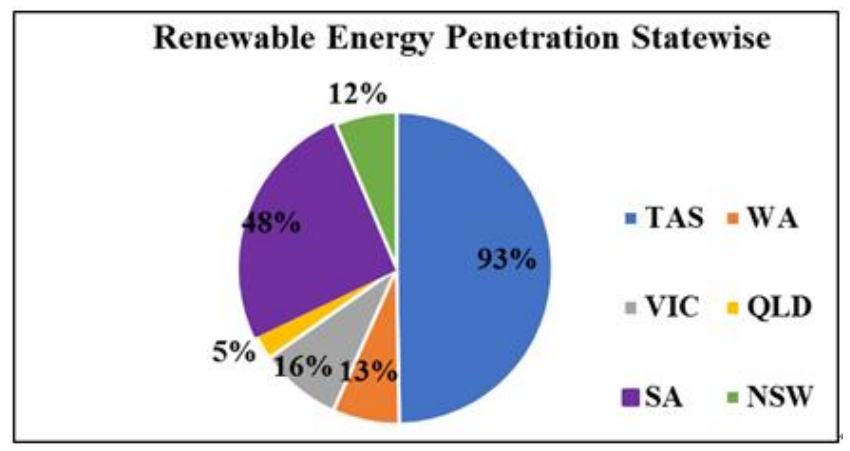

Figure 1. State-wise Renewable Energy utilization in Australia till 2016

\section{AUSTRALIA'S RENEWABLE ENERGY TARGET}

RET was earlier known as the Mandatory Renewable Energy Target (MRET), which came into effect in 2001 to integrate renewable energy into at least $2 \%$ in the Australia's electricity production. In 2009 , the target was elevated up to $20 \%$ of Australia's electricity for about 41,000GWh [12-13]. In January 2011, the RET was bifurcated into:

- $\quad$ Large Scale Renewable Energy Target - This scheme focuses on providing financial incentive/assistance to set up and populate solar energy farms, wind energy farms etc. as a contribution to Australia's 2020 target. Depending on the size of renewable energy produced from the renewable energies (electricity generated from fossil fuels and their waste are not considered), large scale generation certificates are available. These certificates are either tradeable or sold to the entities who are legally responsible for RET or the electricity produced can be sold to the grid. Clean energy regulator annually accepts the surrendered certificates from these liable entities.

- Small Scale Renewable Energy Scheme - This scheme provides financial assistance to install small scale systems like solar panels, wind, solar water heater, air source heat pumps. The small-scale system owners can be individuals or small businesses and are financially assisted through smallscale technology certificates which works like the aforementioned large-scale generation certificates.

\section{STATE RENEWABLE ENERGY TARGET}

To assist in the nation's renewable energy target and mitigation of GHG emissions, state governments have announced their own targets. In 2014, South Australia aimed at producing $50 \%$ of electricity from renewable energy by 2025, nevertheless their existing renewable energy contribution is $40 \%$. The South Australian Government recently has aimed at to attract $\$ 10$ billion investment by 2025 through renewable energy. A Renewable Energy Plan for South Australia was introduced in 2011 to make it the best destination for renewable energy development and investment. The plan includes [14]:

$>$ Tabling legislation to grant energy developers access to Crown lands which are currently subjected to pastoral lease.

$>$ Coming up with a model of community owned solar and supporting the design and implementation of the same.

$>$ Imposing a specific limit on carbon emissions for generation of new electricity.

$>$ Supporting building of solar power concentrators for heating and electricity use in Port Augusta.

Like the Australian Capital Territory which announced RET of $50 \%$ by 2020 in 2014, the State Government of Victoria in 2016 has committed to produce $25 \%$ and $40 \%$ of electricity from renewable energy by 2020 and 2025 respectively. Victoria is bestowed with abundant wind and limited solar energy resources. However the lack of guided energy policies discourages progress towards renewable energy. The state lacks any attractive strategies or policies to attract renewable energy investment. On the other hand, there are very dissuading policies such as prohibited areas for wind generation and giving land owners, the final say in allowing wind turbines to be located. Queensland has announced its share of renewable energy to $50 \%$ by 2030 and has further committed to 1 million rooftops on houses by 2020 . The Queensland government introduced PowerQ which is a 30year strategy to mitigate the emissions between 2016-2026 from its electricity sector. The Government of NSW announced a Renewable Energy Action Plan which includes 24 actions and 3 goals to assist and support renewable energy. The goals consist of:

- $\quad$ Attracting investment in renewable energy.

- Building support of the community towards renewables.

- $\quad$ Attracting and growing expertise in renewable energy.

A Renewable Energy Advocate has been appointed to monitor and assist the renewable energy development of the state. Governments of NSW and ACT with the partnership of Regional Development Australia agencies and 20 large scale industries introduced South East Region of Renewable Energy Excellence (SERREE) to improve the financial investment on renewable energy.

Tasmania has abundant renewable energies namely wind and hydroelectric power sharing $87 \%$ of the state's energy mix. In 2013 , renewables shared $93 \%$ of electricity in the state. 
Tasmania's Climate Action Council was aiming at $100 \%$ renewable energy target by 2020 until the election in 2014, after which it was abandoned.

AP2 is a new climate change strategy and action plan for the Australian Capital Territory, which monitors the state's RET and emissions. This plan highlights the state's expansion of around $690 \mathrm{MW}$ of large-scale renewable energy and $72 \mathrm{MW}$ of small and medium scale solar PV by the end of 2020 .

Northern Territory, though it has abundance of solar energy, does not have any targets for either mitigating the emissions or developing renewable energy. It is also noted that the state lacks a climate change policy [14].

\section{FEED-IN-TARIFF IN AUSTRALIA}

FiTs are the revenue generated when electricity from renewable energies from wind or solar is fed to the grid. The government or electricity retailer usually fixes the tariff. FiTs help in easier adoption of renewable technology by the consumers and make it an economically viable option by decreasing the rate of return period. The customers are paid higher tariffs when they adopt the technology earlier, and this also leads to planning the electricity consumption as per the availability of the resources or minimising the consumption. FiTs are very advantageous for promoting the decentralisation of electricity generation and diversification of electricity generation $[6,15]$. By decentralising electricity generation, electricity supply becomes less susceptible to natural hazards or maintenance issues which may otherwise arise with centralised power supply. Diversification will also help in spreading the risk of energy source lock in and guard against supply risks.

After installation of the eligible RES, the owners or small business units submit their application to be eligible for FiTs and sign a contract (normally for a fixed term) to feed the electricity to the grid. The contracts are valid till the owners reside in the respective properties. The slashed price of solar panels makes it more affordable for most households to reach a part of the respective state's small-scale RET. This has led to a drop in the tariffs, remarkably in the recent decade, to less than $10 \mathrm{c}$ by the state government which has set FiTs to aid its states RET. Complementing the fact of country's natural conditions to harness the renewable sources. A study suggests that PV panels with approximately $15 \%$ efficiency when used in the power station located in Central Australia which has abundant solar radiation to harness, $1.05 \mathrm{kWh} / \mathrm{m}^{2} /$ day of solar energy can be trapped to supply a non-stop energy of $44 \mathrm{~W} / \mathrm{m}^{2}$ in for a day and $32 \mathrm{~W} / \mathrm{m}^{2}$ of energy by considering losses along the distant transmissions [16].

Australia is bestowed with high potential solar radiation which is represented in Figure 2. Considering this fact and counting the population of this country compared to others suggests per capita solar radiation is incomparable to other countries. This implies that solar radiation has potential to cater to the energy demands [17]. According to the reports, South Australia and Queensland are competing to become the top solar PV rooftop installation states with $30 \%$ of their rooftops having access to solar panels. Similarly, large scale PV installations would escalate to beyond 20 projects of more than $1 \mathrm{GW}$ capacity and $3.7 \mathrm{GW}$ of total large scale solar projects are under proposal [18].

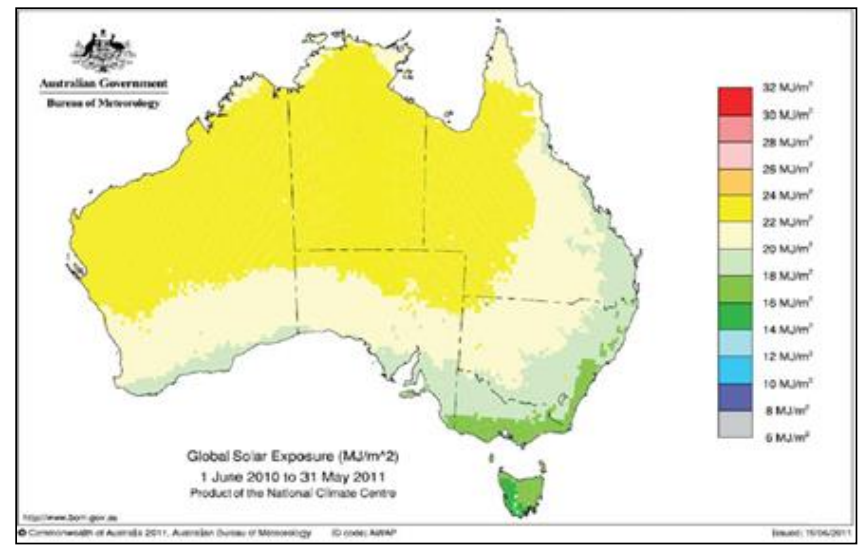

Figure 2. Annual average of daily solar exposure in Australia

Table 1 illustrates the total of 5444MW PV installations the Australian states as on December 2016. About 1602MW and 1314MW solar installations has been made by Queensland and New South Wales respectively. Victoria has installed 968 MW of PV, 690MW and 645MW of installations in South Australia and Western Australia, while Australian Capital Territory, Tasmania and Northern Territory have installed 77MW, 98MW and 50MW respectively [18].

Table 1. Australian Solar installation state wise (as on 1 Dec 2016)

\begin{tabular}{|c|c|c|}
\hline State/Territory & Installations & MW \\
\hline Queensland & 485,794 & 1602 \\
\hline South Australia & 200,213 & 690 \\
\hline Western Australia & 211,091 & 645 \\
\hline Victoria & 294,815 & 968 \\
\hline New South Wales & 343,930 & 1314 \\
\hline Australian Capital Territory & 17,085 & 77 \\
\hline Tasmania & 27,836 & 98 \\
\hline Northern Territory & 6,253 & 50 \\
\hline TOTAL & $1,587,017$ & 5444 \\
\hline
\end{tabular}

The FiTs in the federal states of Australia are as follows:

AUSTRLIAN CAPITAL TERRITORY (ACT): FiT policy in the state of ACT is unique compared to existing $\mathrm{RE}$ policies there. It works on the method of reverse auction through which the project that bids for the lowest price gets sanctioned. This strategy is to attract more investors to the territory. With four renewable energy projects of 640MW and three large scale projects of 200MW between 20142016 through reverse auctions, ACT has an ambitiously put forth its RET to be $100 \%$ by 2020 .Similaly many wind projects are in the pipeline.

$>$ VICTORIA(VIC): The state of Victoria had announced RET of $25 \%$ by 2020 and $40 \%$ (of about $5400 \mathrm{MW})$ by 2025 in mid-2016. Similar to ACT, by implementing a reverse auction scheme to support $1500 \mathrm{MW}$ by 2020 , Victoria has planned to achieve its RET. The FiT was revised in the early 2017 and was doubled compared to the previous year; this encourages the Victorian households to feed in more renewable energy into the grid. With the help of state essential service commission, the Victorian Government is aiming to exploit more solar power in the state. $20 \mathrm{MW}$ of storage array was showcased by sending expressions of interest in February 2017. 
QUEENSLAND (QLD): The Queensland has a very ambitious target to $50 \%$ of power by renewable energy by 2030. Considering the best of climatic condition and large population, Queensland's household solar rooftop penetration is aimed to double compared to the current scenario by one million rooftop penetrations by 2020 . There are many such similar projects in pipeline making Queensland the biggest player in the renewable energy market when compared to other states.

$>$ WESTERN AUSTRALIA (WA): With the recent change in governments in Western Australia, there is a potential for some changes with regards to renewables and FiT to take place. Western Australia because of its size and sparse population spread far and wide makes it a perfect candidate for microgrid with battery storage. Traditional power plants with long transmission lines are a costly option to deploy and maintain. The power companies in Western Australia which are government owned, have been collaborating rather aggressively with the private sector to develop new technologies. Although the state government has not mandated a formal renewable energy target, significant investment is in train for solar farms, wave energy projects and the like.

SOUTH AUSTRALIA (SA): SA has set its RET as $50 \%$ by 2025 .It has also aimed at low carbon generation for the same time frame. In this regard, SA has planned to invest \$2.4 billion. The Australian Energy Market Operator (AEMO) and solar data have put forth the estimation of SA's renewable energy contribution as $48 \%$ in 2016 . The state's North coal fired plant was an additional reason for such escalating RE penetration. This could result in achieving RET much earlier than the targeted time frame. In September 2016, a big Armageddon storm hit SA which smashed the electricity pylons and three major transmission lines resulting in a state-wide black-out due to the overload in the interconnector linking Victoria. This resulted in politicians condemning renewable energy to be the major cause for the aftermath, which AEMO later suggested was a false claim.

$>$ NEW SOUTH WALES (NSW): With a project of $137 \mathrm{GWh}$ of electricity from a renewable energy per annum Sydney Metro North West rail link responded to calls for expression of interest. NSW is on its way to follow ACT and Victoria with reverse auctions schemes

D TASMANIA (TAS): Tasmania unlike the other states has always been a major user of hydropower to generate electricity. This has been since it has lot of hydropower to exploit. And this has been so since the past 100 years. However, in recent past, there has been a reduction in rainfall which has put a strain on the electricity grid. The other way to getting electricity in Tasmania has been through the Basslink cable which connects to the National Electricity Market on the Australian mainland. Recently this suffered a huge outage further putting strain on the electricity network in Tasmania. Due to all these issues, there has been a renewed focus on using renewables to ease the problems encountered, one of the activity has been a feasibility analysis that will be performed by the (ARENA) Australian Renewable Energy Agency about the possibility of adding 200MW worth of pumped hydro storage.

Table 2 provides the FiTs provided by the state government and retailers for renewable energy implementation. These are the FiTs as on September 2017. However, it was noted that states like Victoria allowed the FiTs for other renewable energy systems like wind and hydro-energy but retailers from the states like Western Australia supported FiTs for solar energy systems alone. It was also observed that NT had further restrictions for PV based off-grid due to the use of isolated power generation within this state.

Table 2. FiTs state-wise as on 2017

\begin{tabular}{|c|c|c|c|}
\hline State & $\begin{array}{c}\text { Feed in Tariff } \\
\text { Price }\end{array}$ & $\begin{array}{c}\text { Type } \\
\text { Allowed } \\
\end{array}$ & Retailers Contact \\
\hline VIC & $11.3 \mathrm{c}$ & $\begin{array}{l}\text { PV, Wind \& } \\
\text { Hydro }\end{array}$ & $\begin{array}{c}\text { Essential Services } \\
\text { Commission [20], } \\
\text { AGL [21] }\end{array}$ \\
\hline NSW & $11.1 \mathrm{c}$ & $\begin{array}{c}\text { PV, Wind \& } \\
\text { Hydro }\end{array}$ & $\begin{array}{c}\text { EnergyMadeEasy } \\
{[22]}\end{array}$ \\
\hline $\mathrm{SA}$ & $16.3 \mathrm{c}$ & $\begin{array}{l}\text { PV, Wind \& } \\
\text { Hydro }\end{array}$ & $\begin{array}{c}\text { EnergyMadeEasy } \\
{[22]}\end{array}$ \\
\hline QLD & $10.6 \mathrm{c}$ & $\begin{array}{c}\text { PV, Wind \& } \\
\text { Hydro }\end{array}$ & $\begin{array}{c}\text { EnergyMadeEasy } \\
{[22]}\end{array}$ \\
\hline TAS & $8.93 \mathrm{c}$ & $\begin{array}{c}\text { PV, Wind \& } \\
\text { Hydro }\end{array}$ & $\begin{array}{c}\text { EnergyMadeEasy } \\
{[22]}\end{array}$ \\
\hline $\mathrm{ACT}$ & $6-7.5 c$ & PV \& Wind & $\begin{array}{c}\text { EnergyMadeEasy } \\
{[22]}\end{array}$ \\
\hline NT & $\begin{array}{l}14.83 \mathrm{c}(45 \mathrm{c} \text { in } \\
\text { Alice Springs) }\end{array}$ & $\begin{array}{c}\text { PV, Wind \& } \\
\text { Hydro }\end{array}$ & PowerWater [23] \\
\hline WA & $7.13 \mathrm{c}$ & $\begin{array}{l}\text { PV, Solar } \\
\text { Thermal, } \\
\text { Wind \& } \\
\text { Hydro }\end{array}$ & $\begin{array}{c}\text { Government of } \\
\text { Western Australia } \\
{[24]}\end{array}$ \\
\hline
\end{tabular}

\section{SIMULATION STUDY FOR FITS IN THE AUSTRALIAN STATES}

The advantage of adaption of renewable energy through FiTs might be best understood through a model that considers the energy consumption for a university building and electricity bills for three years. Assuming that the university to be in all the states of Australia the effect of FiTs on the economics for renewable energy system is analysed. For this study, Hybrid Optimisation Model for Electric Renewable (HOMER PRO) software is used to optimally size the RES and conducting economic analysis by considering the Net Present Cost (NPC) and Levelised cost of Energy (COE) of the system as the performance indicators.

- Net Present Cost (NPC): Net Present Cost determines the profitability of the project, which is the total net present value of the component subtracted by the (income) profit it incurs for the complete lifetime of the project as shown in equation (1).

$N P C=\sum\left(\frac{\text { Total Cash flow }}{1+\text { Rate of Interest }}\right)-$ Initial Investment

- Annualized cost: Annualized cost is that cost of the set up when factored equally over the entire lifetime of the project considered, as shown in equation (2).

Annualized Cost $=\frac{\text { TotalCost of the project } \times \text { Discount rate }}{1-(1+\text { Discount rate })^{- \text {lifetime }}}$

- Levelised cost of Energy (COE): It is the average cost of useful electrical energy produced by the system. To calculate the Levelised cost of energy, HOMER divides the 
annualized cost of producing electricity (the total annualized cost minus the cost of serving the thermal load) by the total electric load served, using equation (3):

COE $=\frac{\text { Total Annual Electriicty Production }}{\text { Load Served by the system }}$

- Renewable energy penetration: It is the amount of renewable energy that serves the load annually.

Since the FiTs are uniformly provided for PV system and wind energy systems in all the states of Australia, solar energy systems and wind energy systems connected to the grid are sized for different locations. The electricity price for every state is considered from AEMO database.

\subsection{HOMER PRO software analysis}

The HOMER, now called HOMER PRO is the most widely used and reliable software to perform renewable energy system sizing and optimization. This software aids in performing feasibility test for different renewable energy configurations of various sizes, while it also performs sensitivity analysis for a set of configurations for the desired energy systems. National Renewable Energy Laboratory (NREL) USA developed this software for both off grid and grid connected applications in 1993 [25]. In designing a microgrid, many decisions regarding the micro-grid configurations need to be made. These include the components in the system design, component sizing etc. The decision making for these criteria relies on the renewable energy technology options that are available at the desired location and the availability of the resources. Hence, it is a crucial task to choose the location for the desired micro-grid to set up. Different renewable energy technologies like PV, wind, hydrogen fuel cell etc. are considered. The component costs, the inflation rate, the interest rate, resource availability and technical details of the desired components are also considered.

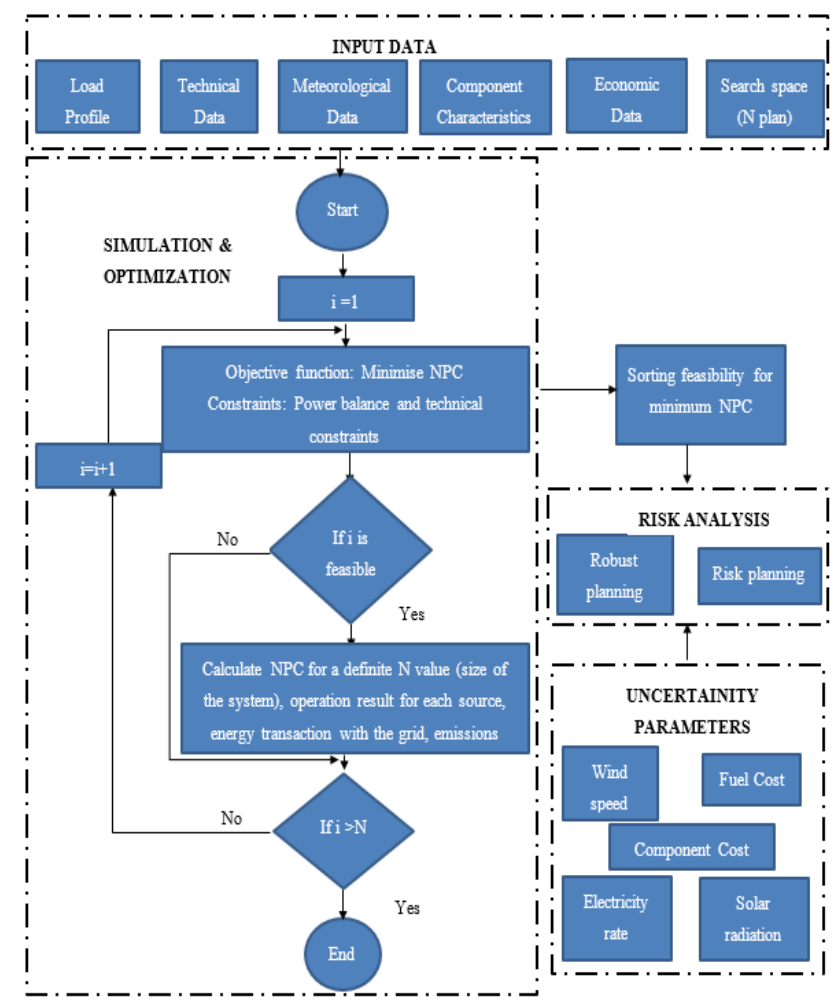

Figure 3. Algorithm used by HOMER for analysis [26]
The algorithm used by the HOMER software is shown in Figure 3. By considering user defined input data, uncertainty parameters and risk analysis, the optimization and simulation are done for each combination of hybrid renewable energy sources (HRES) from search space. HOMER calculates the optimal size of the HRES on considering the objective function and constraints defined by the user. Minimising the NPC of the system would be the objective function by considering the system's operation and maintenance cost, capital cost and replacement cost, cost of the fuel if any, revenue incurred (selling the excess energy through the grid and salvage cost). These calculations are made for every oneminute time step for a complete year (8760-time steps) including the power balance constraint for feasibility. At the end of each iteration, the feasible solutions are sorted according to the minimum or least value of NPC. In the analysis, HOMER also considers sensitive variables or uncertainty parameters as fuel cost, wind speed, solar radiation, electricity price, and components cost. After a set of HRES combinations are resulted at the end of the iterations, HOMER generates set of figures to examine the output for all the uncertainty parameters considered [26].

\subsection{Input factors for analysis}

The simulation study conducted using HOMER PRO included the analysis of the energy consumption data by studying the university's electricity bills. However, the electricity price would vary from state to state. Thus, the average electricity price for a year (2015-2016) was considered from AEMO shown in Table 3. The other inputs which are discount rate and inflation rate, were $5.32 \%$ and $2.1 \%$ respectively for 20 years [27].

Table 3. Average Electricity Price in 2015-2016 state-wise

\begin{tabular}{|c|c|c|c|c|c|}
\hline Year & NSW & QLD & SA & TAS & VIC \\
\hline $2000-01$ & 37.69 & 41.33 & 56.39 & & 44.57 \\
\hline $2001-02$ & 34.76 & 35.34 & 31.61 & & 30.97 \\
\hline $2002-03$ & 32.91 & 37.79 & 30.11 & & 27.56 \\
\hline $2003-04$ & 32.37 & 28.18 & 34.86 & & 25.38 \\
\hline $2004-05$ & 39.33 & 28.96 & 36.07 & 190.38 & 27.62 \\
\hline $2005-06$ & 37.24 & 28.12 & 37.76 & 56.76 & 32.47 \\
\hline $2006-07$ & 58.72 & 52.14 & 51.61 & 49.56 & 54.80 \\
\hline $2007-08$ & 41.66 & 52.34 & 73.50 & 54.68 & 46.79 \\
\hline $2008-09$ & 38.85 & 34.00 & 50.98 & 58.48 & 41.82 \\
\hline $2009-10$ & 44.19 & 33.30 & 55.31 & 29.37 & 36.28 \\
\hline $2010-11$ & 36.74 & 30.97 & 32.58 & 29.45 & 27.09 \\
\hline $2011-12$ & 29.67 & 29.07 & 30.28 & 32.58 & 27.28 \\
\hline $2012-13$ & 55.10 & 67.02 & 69.75 & 48.30 & 57.44 \\
\hline $2013-14$ & 52.26 & 58.42 & 61.71 & 41.98 & 51.49 \\
\hline $2014-15$ & 35.17 & 52.52 & 39.29 & 37.16 & 30.35 \\
\hline $2015-16$ & 49.36 & 58.78 & 58.28 & 104.27 & 43.95 \\
\hline
\end{tabular}

Five states namely Victoria, NSW, Queensland, SA, Tasmania were considered for the analysis and the locations considered for the study are Warrnambool, Victoria; Minimbah, New South Wales (NSW), Nindaroo, Queensland, Cleve, South Australia (SA) and Stony Head, Tasmania. The chosen locations are shown in Figure 4. The places chosen were not the state capitals and there has not been much renewable energies from these locations. Due to the lack of availability of electricity price data WA has not been considered and due to the restriction imposed for PV based off-grid due to the use of isolated power generation within this 
state, these two states have not been explored for FiTs analysis.

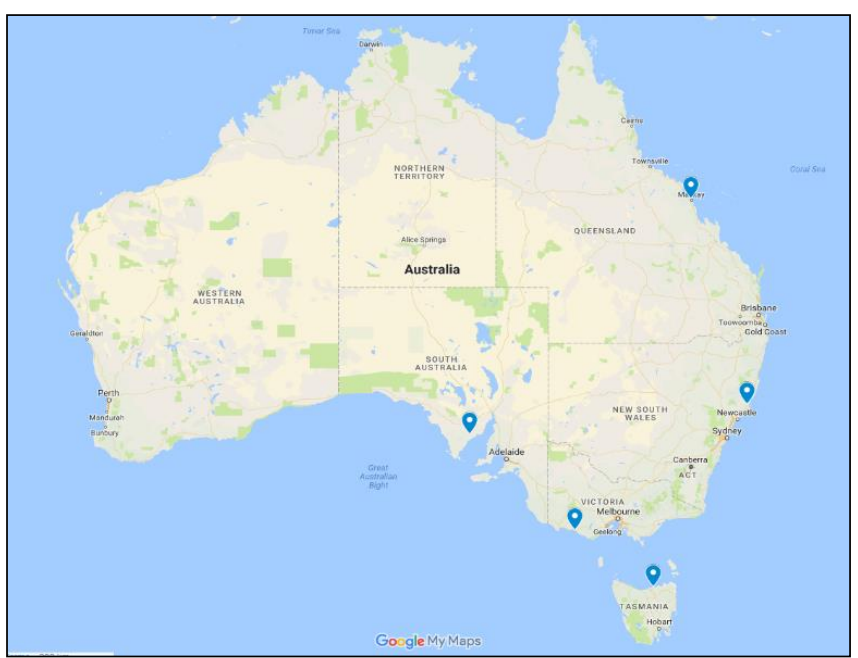

Figure 4. Locations considered for the study in five states of Australia

Figure 5-7 represents the average solar radiation and clearness index for the five locations, monthly average wind speed in the desired locations and annual average solar radiation and Wind speed at the desired locations respectively. The average solar radiation and clearness index varies from a minimum of $1.77 \mathrm{kWh} / \mathrm{m}^{2} /$ day and 0.46 in June to a maximum of $6.5 \mathrm{kWh} / \mathrm{m}^{2} /$ day and 0.542 in January at Warrnambool respectively. The annual average daily solar radiation at Warrnambool is $4.18 \mathrm{kWh} / \mathrm{m}^{2} /$ day. Similarly, at Minimbah, NSW, the average solar radiation and clearness index varies from a minimum of $2.57 \mathrm{kWh} / \mathrm{m}^{2} /$ day in June and 0.5 in May to a maximum of $6.49 \mathrm{kWh} / \mathrm{m}^{2} /$ day in December and 0.559 in August and September. The annual average solar radiation at Minimbah is $4.59 \mathrm{kWh} / \mathrm{m}^{2} /$ day as shown in Figure 5. The average daily solar radiation at Nindaroo, Queensland, the average solar radiation and clearness index varies from a minimum of $7.74 \mathrm{kWh} / \mathrm{m}^{2} /$ day in June and 0.53 in April to a maximum of $6.65 \mathrm{kWh} / \mathrm{m}^{2} /$ day in November and 0.624 in September. The annual average solar radiation at Nindaroo is $5.32 \mathrm{kWh} / \mathrm{m}^{2} /$ day as shown in Figure 7 . At Cleve, SA, the average solar radiation and clearness index varies from a minimum of $2.44 \mathrm{kWh} / \mathrm{m}^{2} /$ day in June and 0.528 in May to a maximum of $6.89 \mathrm{kWh} / \mathrm{m}^{2} /$ day and 0.575 in January respectively. From Figure 5 it can be noted that the annual average solar radiation at Nindaroo is $4.72 \mathrm{kWh} / \mathrm{m}^{2} /$ day. At Stony Head, Tasmania, the average solar radiation and clearness index varies from a minimum of $1.55 \mathrm{kWh} / \mathrm{m}^{2} /$ day in June and 0.451 in July to a maximum of $6.36 \mathrm{kWh} / \mathrm{m}^{2} /$ day in December and 0.526 in February respectively. The annual average solar radiation at Stony Head, Tasmania is $3.95 \mathrm{kWh} / \mathrm{m}^{2} /$ day.

The monthly average wind speed for Warrnambool in Victoria is a maximum of $7 \mathrm{~m} / \mathrm{s}$ in august to a minimum of $5.16 \mathrm{~m} / \mathrm{s}$ in March as shown in Figure 6. Similarly, at Minimbah, NSW, the monthly average wind speed is maximum of $6.6 \mathrm{~m} / \mathrm{s}$ in August and a minimum $4.82 \mathrm{~m} / \mathrm{s}$ in February. The monthly average wind speed at Nindaroo, Queensland varies from a maximum of $6.45 \mathrm{~m} / \mathrm{s}$ in April to a minimum of $5.53 \mathrm{~m} / \mathrm{s}$ in May. The monthly average windspeed at Cleve, SA varies from a maximum of $6.02 \mathrm{~m} / \mathrm{s}$ in August to a minimum of $4.88 \mathrm{~m} / \mathrm{s}$ in May. The monthly average wind speed at Stony Head, Tasmania is maximum compared to the other places, it varies from a maximum of $8.42 \mathrm{~m} / \mathrm{s}$ in August to a minimum of $6.76 \mathrm{~m} / \mathrm{s}$ in March. When the annual average windspeed is considered as illustrated in Figure 7, Tasmania has the maximum of $7.5 \mathrm{~m} / \mathrm{s}$, Queensland with annual average windspeed of $6.01 \mathrm{~m} / \mathrm{s}$. Victoria, NSW and SA has an annual average windspeed of $5.96 \mathrm{~m} / \mathrm{s}, 5.51 \mathrm{~m} / \mathrm{s}, 5.43 \mathrm{~m} / \mathrm{s}$ respectively.

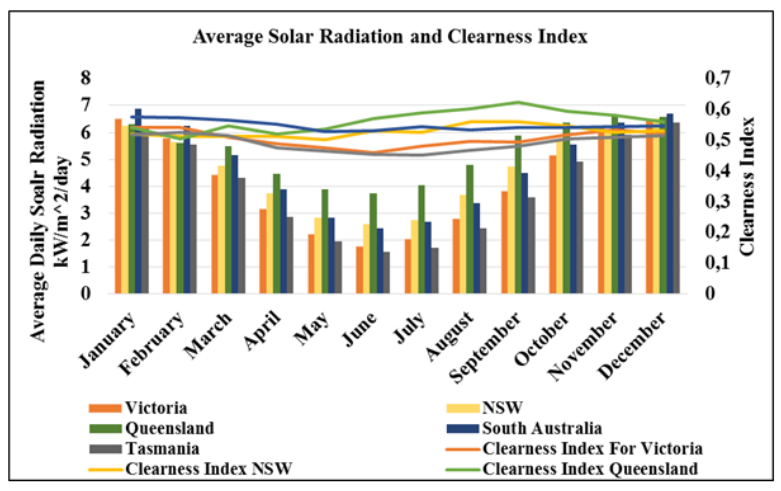

Figure 5. Average solar radiation and clearness index for the study case

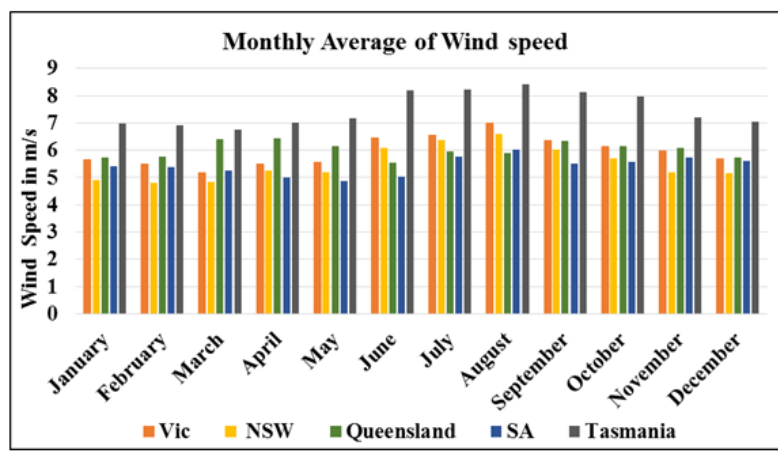

Figure 6. Monthly average wind speed in the desired locations in Australia

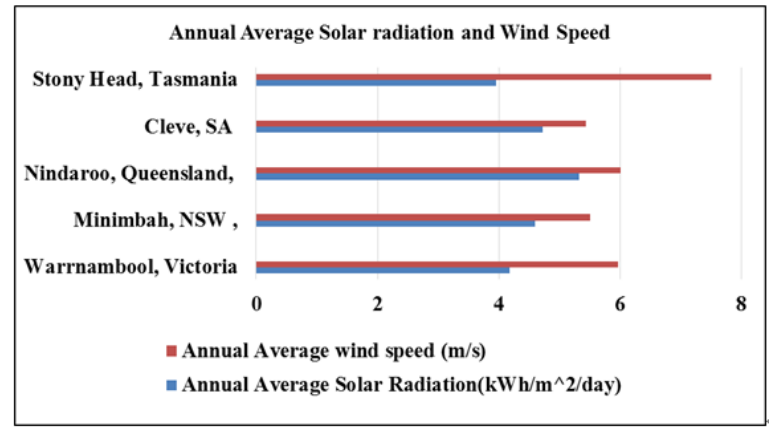

Figure 7. Annual average solar radiation and wind speed at the desired locations

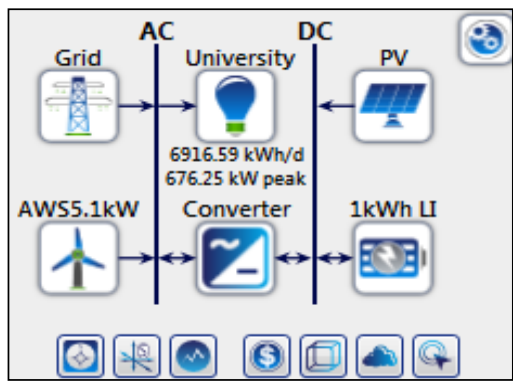

Figure 8. Schematic diagram of HRES considered 
Since these locations had a consistently good solar radiation and windspeed. PV and wind turbine were considered as RES to exploit the available resources as shown in the schematic diagram in Figure 8. The presence of grid in this model was for energy transactions to explore the benefits of FiTs. Further, battery of $7000 \mathrm{kWh}$ was considered which is equivalent to energy demand of the university in a day. The size of these
HRES were fixed as illustrated in Table 4 to understand the sizing of HRES for different solar and wind energy availabilities.

The analysis was made considering an option of FiTs provided by the respective states and FiTs made equivalent to power tariff for the respective state. The analysis considered only PV and wind as sources of energies.

Table 4. The size of HRES considered for the study

\begin{tabular}{|c|c|c|c|c|}
\hline Components & Capital & Replacement & $\begin{array}{c}\text { Operation \& } \\
\text { Maintenance }\end{array}$ & Size Constraint \\
\hline PV (kW) & 680 & 680 & 10 & 7000 \\
\hline AWS 5.1kW & 35,000 & 35,000 & 3500 & $0-1$ \\
\hline System Converter(kW) & 240 & 240 & 0 & 1000 \\
\hline $1 \mathrm{kWh}$ Li-Ion Battery & 50 & 50 & 10 & 7000 \\
\hline
\end{tabular}

\section{RESULTS AND DISCUSSIONS}

To explore the advantages that the government of Australia has provided, the energy cost for each location was examined. Table 5 shows the economic analysis of the RES with and without wind turbine which are represented as Case- 1 and 2. The regular FiTs provided by were provided was considered, and another case of FiTs equal to the grid price was considered. The COE, NPC and Renewable Energy fraction have been considered as the performance indicator for the economic criteria. When Case-1 and 2 were compared for all the states, it was observed that greater renewable energy (with two renewable energy sources) provided larger COE, NPC and Renewable Energy Fraction. Though the difference between Case- 1 and 2 are not very much, they are quite significant.

The study also signifies that when the FiT were made equivalent to the grid price, there was significant difference of nearly $15 \%-20 \%$ in the Renewable energy penetration, COE and NPC. There is a steep drop in the COE, NPC while the RE penetration increased. Considering the actual FiTs of the locations considered, Tasmania has the smallest FiTs with \$0.089 and SA gives the highest FiTs of \$0.163, the COE and NPC of the RES for SA is much smaller of about $\$ 0.008$ and $\$ 0.0088$ for Case- 1 and Case- 2 respectively. The NPC of RES for SA scenario is the least compared to any other states with $\$ 853,721$ and $\$ 943,652$ for Case 1 and Case 2. respectively. The results obtained from HOMER also elucidates the RE fraction or penetration is higher for Tasmania scenario of about $75.5 \%$ and $75.7 \%$ for Case- 1 and Case- 2 respectively compared to SA which has $60.5 \%$ for both Case- 1 and Case. When the FiTs of Victoria, NSW and Queensland scenarios were considered, the FiTs for Victoria were highest $\$ 0.113$ while NSW and Queensland have the FiTs of $\$ 0.111$ and $\$ 0.106$ respectively. The COE, NPC and RE penetration when considered, the COE and NPC for Victoria is the least with $\$ 0.0359$ and $3.82 \mathrm{M}$ respectively for Case- 1 and 0.0367 and $3.91 \mathrm{M}$ for Case-2. The RE penetration for both the cases is approximately $56 \%$ which is smaller than the RE penetration of NSW and Queensland. This implies smaller renewable energy penetration has resulted for RES with smaller COE and NPC when Victoria, NSW and Queensland scenarios were considered. This is due to the fact that the RE availability for Victoria is less compared to NSW and Queensland.

When the FiTs were made equivalent to the state's electricity/grid price, there was tremendous improvement in the COE, NPC and RE penetration for all the states except Tasmania. In the case of Tasmania, the grid price is higher than the FiTs by $\$ 0.11 / \mathrm{kWh}$; this is highlighted as smaller RE penetration for Tasmania when grid price was considered as FiTs. A minimum of $15 \%$ RE penetration was observed in the other four states when FiTs were made equivalent to grid price. A noticeable increase in the RE penetration of approximately $20.5 \%$ was observed for Victoria, $18.3 \%$ increase for NSW, $17.2 \%$ increase in SA and $15.5 \%$ increase in Queensland. The COE, NPC, RE penetration were similar between NSW and Victoria as the differences between the government provided FiTs and grid price for both the states were equivalent. Similar relationship between COE, NPC and RE penetration was observed between Queensland and SA. The results signify that when the FiTs are smaller, the COE is smaller as the FiTs are made equivalent to the grid.

Table 5. Economic analysis of the HRES considered in the desired locations in Australia

\begin{tabular}{|c|c|c|c|c|c|c|c|}
\hline \multirow{2}{*}{} & FiTs(AUD/kWh) & \multicolumn{2}{|c|}{ COE (AUD) } & \multicolumn{2}{c|}{ NPC (AUD) } & \multicolumn{2}{c|}{$\begin{array}{c}\text { Renewable energy Fraction } \\
(\%)\end{array}$} \\
\cline { 2 - 8 } & & & Case-1 & Case-2 & Case-1 & Case-2 & \multicolumn{2}{c|}{ Case-1 } & Case-2 \\
\hline \multirow{2}{*}{ Warrnambool, Victoria } & 0.113 & 0.0359 & 0.0367 & $3.82 \mathrm{M}$ & $3.91 \mathrm{M}$ & 55.9 & 56 \\
\cline { 2 - 8 } & 0.044 & 0.0969 & 0.0980 & $7.55 \mathrm{M}$ & $7.64 \mathrm{M}$ & 76.4 & 76.5 \\
\hline \multirow{2}{*}{ Minimbah, NSW } & 0.11 & 0.0364 & 0.0372 & $7.35 \mathrm{M}$ & $7.44 \mathrm{M}$ & 59 & 59.1 \\
\cline { 2 - 8 } & 0.049 & 0.0915 & 0.0926 & $3.92 \mathrm{M}$ & $4.01 \mathrm{M}$ & 77.3 & 77.4 \\
\hline Nindaro, Queensland, & 0.106 & 0.0382 & 0.039 & $4.2 \mathrm{M}$ & $4.29 \mathrm{M}$ & 63.1 & 63.1 \\
\cline { 2 - 8 } & 0.058 & 0.0854 & 0.0864 & $7.03 \mathrm{M}$ & $7.12 \mathrm{M}$ & 78.5 & 78.6 \\
\hline \multirow{2}{*}{ Cleve, SA } & 0.163 & 0.00792 & 0.00874 & 853,721 & 943,652 & 60.5 & 60.5 \\
\cline { 2 - 8 } & 0.058 & 0.089 & 0.0901 & $7.16 \mathrm{M}$ & $7.25 \mathrm{M}$ & 77.6 & 77.7 \\
\hline \multirow{2}{*}{ Stony Head, Tasmania } & 0.089 & 0.101 & 0.102 & $7.78 \mathrm{M}$ & $7.86 \mathrm{M}$ & 75.5 & 75.7 \\
\cline { 2 - 8 } & 0.20 & 0.0282 & 0.0273 & $2.65 \mathrm{M}$ & $2.67 \mathrm{M}$ & 57.5 & 53.4 \\
\hline
\end{tabular}




\section{SUGGESTIONS FOR FITS ADAPTION}

FiTs are of two types.

- Gross FiT - All the electricity produced by the renewable source is bought from the producer at a very good price and then the generator themselves buy the electricity needed back from the gird for their personal use.

- $\quad$ Net FiT - Tariff paid to the renewable energy based electricity producer for purchasing their surplus/unused electricity.

Though FiTs encourage renewable energy adaption in the form of revenue through the generation, there are many disadvantages. FiTs are generation and location specific, this is also noted from Table 6. The FiTs are available only for certain renewable energy generation in different states. Mainly energy generated from PV can benefit from FiTs and sometimes Wind generations (e.g. State Victoria). FiTs are not available for other source of renewable energy generators. This makes the other Renewable energy sources less exploited which makes it tough for the RET. There is disagreement in the tariff set between The Government regulated FiTs and FiTs provided by the retailers. When the retailers were contacted for the FiTs study in the states considered, it was noticed that at some of the states, though the Government specified the FiTs for the RES like solar and wind energy systems, the retailers provided FiTs to PV only systems. This also makes other RES less exploited. The government sets the FiTs, and the prices changed in a timely manner, this has resulted in lack of updated information reaching the renewable energy adaptors.

The government organisations must monitor the timely upgradation of the information. At many times when FiTs were set to a very low price leading to a huge loss in the RE, resulting in lack of RE adaption drive. FiTs set by the Government and the FiTs provided by the retailer must be in unison, or else this could result in further confusions with the consumers/ RES installers. This may de-mean the RE adaption and make the easily available grid option more convenient. This could challenge the growth of RE in the country.

Table 6. Current status summary of all the states in Austria [11]

\begin{tabular}{|c|c|}
\hline State/Territory & Current Status Summary \\
\hline Queensland & $\begin{array}{l}\text { - } \quad 50 \% \text { renewable energy } \\
\text { by } 2030 \\
\text { - } \quad \text { Net zero emissions by } \\
2050 \text {. } \\
\quad \text { - } \quad 7 \% \text { RE share }\end{array}$ \\
\hline South Australia & $\begin{array}{ll}\text { - } & 50 \% \text { renewable energy } \\
\text { by } 2025 \\
\text { - } & \text { Net zero emissions by } \\
& 2050 \\
\text { - } & 47 \% \text { of RE contribution } \\
\text { is from SA }\end{array}$ \\
\hline Western Australia & $\begin{array}{ll}- & \text { No renewable energy } \\
\text { target } \\
\text { - } & \text { No net zero emissions } \\
& \text { target } \\
\text { - } & 7 \% \text { of RE contribution } \\
\end{array}$ \\
\hline Victoria & $\begin{array}{lc}\bullet & 25 \% \text { renewable energy } \\
\text { by } 2020 & 40 \% \text { renewable energy } \\
\text { by } 2025 \\
\text { - } \\
\text { Net zero emissions by } \\
2050 \\
\text { - } & 12 \% \text { of RE contribution } \\
\end{array}$ \\
\hline
\end{tabular}

\begin{tabular}{|c|c|c|}
\hline New South Wales & $\begin{array}{l} \\
\bullet \\
\bullet\end{array}$ & $\begin{array}{l}\text { No renewable energy } \\
\text { target } \\
\text { Net zero emissions by } \\
2050 \\
17 \% \text { RE penetration }\end{array}$ \\
\hline Australian Capital Territory & $\begin{array}{l} \\
\bullet \\
\bullet\end{array}$ & $\begin{array}{l}100 \% \text { renewable energy } \\
\text { by } 2020 \\
\text { Net zero emissions by } \\
2050 \\
22 \% \text { RE contribution }\end{array}$ \\
\hline Tasmania & $\begin{array}{l}\bullet \\
\bullet \\
\bullet\end{array}$ & $\begin{array}{l}100 \% \text { renewable energy } \\
\text { by } 2022 \\
\text { Net zero emissions by } \\
2050 \\
92 \% \mathrm{RE} \text { contribution }\end{array}$ \\
\hline Northern Territory & & $\begin{array}{l}50 \% \text { renewable energy } \\
\text { by } 2030 \\
\text { No net zero emissions } \\
\text { target } \\
2 \% \text { RE contribution }\end{array}$ \\
\hline
\end{tabular}

When solar energy adaption is considered, for instance, the solar radiation varies from place to place, hence the FiT could be fixed to exploit any renewable energies that are abundantly available at five states or locations. Providing competitive FiTs could help in easy adaption. If this competitive price was made equivalent to the conventional electricity price, there would be higher advantage in RE adaption. This could also lead to further innovations in the RES. Government must monitor and make timely changes in FiTs according to the available energy resources and facilitate convenient adaptability to break the stereotypic energy consumption. In countries like Denmark there have been several instances of citizens participating in the drive to adapt RE [28]; Australia has never claimed such events yet. Hence it is also necessity for citizen participation and educating them in adapting RE.

\section{CONCLUSION}

Despite the fact that Australia is bestowed with abundance of RE, it uses coal as the main source for its energy. This study highlights the drive to RE adaption, and easier adaption in university like buildings to improve their micro-grid. This study suggests that there is a lack in the FiTs set by the Government in parallel to the available energy resources and retailers providing FiTs to the RE installers. The RE adaption study was aimed at exploring FiT options for the five prominent states in Australia, where not much RE has been explored. The most commonly used RE adaption methods are grid connected or stand-alone type. A stand-alone method could result in either oversized RES making the RES more expensive or an under-sized RES model for the load demand (which has seasonal variation). This could limit the RE usage. Thus, a grid connected RES along with a set of batteries would be an optimum solution. This solution could be further encouraged by providing necessary rebates and competitive FiTs which could drive the RE adaption. Australia lacks citizen participation in RE adaption. In the middle of Australia's RET target achievement journey, coherent focus on FiTs and their improvement can assist in Australia achieving its RET.

Regardless of the effect FITs are having on renewable energy adoption, the society in general is on the brink of a huge energy transformation in terms of supply and demand. The fact 
that efficiency of small scale PV's and solar concentrators are on the rise [29] and not to neglect the effect battery storage will have on the renewable use. In the near future it is expected that the battery storage cost will be reducing nearing the cost of grid supplied energy [30]. There are a lot of reasons to be upbeat about renewable energy adoption especially since the $\mathrm{PV}$ and related technology are improving and the focus on integrating them [31-32] into the conventional electricity grids has also become one of the areas of prime focus of the electricity companies worldwide.

Disregarding the differences in the energy systems and the policies that are needed to enable renewable energy update, there is a real possibility of the transition of the energy system happening in such a way that the number of disconnections from the electricity grid will increase. With the best example is the Tessla battery connected to the grid along with the RES like PV and Wind turbine in SA revolutionises the battery storage technology. This presents policymakers a good possibility of taking lessons from Australia's experience while applying it elsewhere. Thus, a striking balance between RE claimable FiTs needs to be set according to the available energy resources. By looking at improving on the shortfall to reach the RET, Australia can easily become one of the forerunners in RE exploitation. Nevertheless, if Australia increases the emission trading scheme and provide a better rebate on RES and easy loan with lower interest rates, it can achieve its RET well before the stipulated time frame.

\section{ACKNOWLEDGMENT}

The authors wish to acknowledge Anil Chaudhary from Greenova Solutions Pty Ltd, St Albans, VIC 3021, for helping in providing the current market prices of the renewable energy system used in our study.

\section{REFERENCES}

[1] Sun P, Nie PY. (2015). A comparative study of feed-in tariff and renewable portfolio standard policy in renewable energy industry. Renewable Energy 74: 255262. https://doi.org/10.1016/j.renene.2014.08.027

[2] Kobos PH, Erickson JD, Drennen TE. (2006). Technological learning and renewable energy costs: implications for US renewable energy policy. Energy Policy 34: 1645-1658 https://doi.org/10.1016/j.enpol.2004.12.008

[3] Australia PO. (2017). Renewable energy policy: Retreat, renewal and revitalisation? Available: http://www.aph.gov.au/About_Parliament/Parliamentar y Departments/Parliamentary_Library/pubs/BriefingBo ok45p/RenewableEnergy.

[4] Mendonça M, Scheer H. (2009). Feed-in tariffs: Accelerating the deployment of renewable energy. International Journal of Environmental Studies 67(3): 463. https://doi.org/10.1080/00207230701737011

[5] REN21. (2016). Renewables 2016 Global Status Report. Technical Report.

[6] Moner-Girona M, Ghanadan R, Solano-Peralta M, Kougias I, Bódis K, Huld T, Szabó S. (2016). Adaptation of Feed-in Tariff for remote mini-grids: Tanzania as an illustrative case. Renewable and Sustainable Energy Reviews

53:

306-318 https://doi.org/10.1016/j.rser.2015.08.055

[7] Couture T, Gagnon Y. (2010). An analysis of feed-in tariff remuneration models: Implications for renewable energy investment. Energy Policy 38: 955-965. https://doi.org/10.1016/j.enpol.2009.10.047

[8] Shiroudi A, Rashidi R, Gharehpetian GB, Mousavifar SA Akbari Foroud A. (2012). Case study: Simulation and optimization of photovoltaic-wind-battery hybrid energy system in Taleghan-Iran using homer software. Journal of Renewable and Sustainable Energy 4: 053111. https://doi.org/10.1063/1.4754440

[9] Elliston B, Diesendorf M, MacGill I. (2017). Reliability of $100 \%$ renewable electricity supply in the Australian national electricity market. Towards $100 \%$ Renewable Energy ed: 297-303. https://doi.org/10.1007/978-3-319-45659-1 32

[10] Government A, Department of Industry IAS. (2017). Australian Energy Statistics. Available: https://industry.gov.au/Office-of-the-Chief Economist/Publications/Pages/Australian-energystatistics.aspx.

[11] Council CE. (2016). Clean Energy Australia Report 2016.

[12] Council CE. (2017). Renewable Energy Target. Available:

https://www.cleanenergycouncil.org.au/policyadvocacy/renewable-energy-target.html.

[13] Byrnes L, Brown C, Foster J, Wagner LD. (2013). Australian renewable energy policy: Barriers and challenges. Renewable Energy 60: 711-721. https://doi.org/10.1016/j.renene.2013.06.024

[14] Flannery T. (2014). The Australian renewable energy race: Which states are winning or losing. http://apo.org.au/node/42300 c9b01df1 1ecc6e3dd2184.pdf. Date Accessed: 16.3.2017.

[15] Zahedi A. (2010). A review on feed-in tariff in Australia, what it is now and what it should be. Renewable and Sustainable Energy Reviews 14: 3252-3255. https://doi.org/10.1016/j.rser.2010.07.033

[16] Trainer T. (2012). Can Australia run on renewable energy? The negative case. Energy Policy 50: 306-314.

[17] Zahedi A. (2010). Australian renewable energy progress. Renewable and Sustainable Energy Reviews 14: 22082213. https://doi.org/10.1016/j.rser.2010.03.026

[18] Stock P, Stock A, Bourne G. (2017). State of solar 2016: Globally and in Australia. Climate Council of Australia. Available:

http://www.climatecouncil.org.au/uploads/4127a8c364c 1f9fa8ab096b04cd93f78.pdf. Date Accessed: 15.3.2017.

[19] Mishra Y, Ledwich G, Ghosh A, George T. (2012). Long term transmission planning to meet renewable energy targets in Australia. 2012 IEEE Power and Energy Society General Meeting, pp. 1-7. https://doi.org/10.1109/PESGM.2012.6345250

[20] Comission ES. (2017). Feed-In Tariffs. Available: http://www.esc.vic.gov.au/project/energy/2134minimum-feed-in-tariff/. Date Accessed 2.08.2017

[21] AGL. (2017). AGL increases retailer solar feed in tariffs. AGL, Ed., ed, 2017.

[22] Government A, Regulator AE. (2017). Compare energy offers. Available: https://www.energymadeeasy.gov.au/offer-search. Date Accessed on 12.9.2017.

[23] PowerWater (2017). Photovoltaic (PV) solar systems. Available: 
http://www.powerwater.com.au/customers/save/photov oltaic_pv_solar_systems.

[24] Australia GOW, Treasury DO. (2017). Public Utilities Office.

[25] Sinha S, Chandel SS. (2014). Review of software tools for hybrid renewable energy systems. Renewable and Sustainable Energy Reviews 32: 192-205. https://doi.org/10.1016/j.rser.2014.01.035

[26] Bahramara S, Moghaddam MP, Haghifam MR. (2016). "Optimal planning of hybrid renewable energy systems using HOMER: A review. Renewable and Sustainable Energy Reviews 62: 609-620. https://doi.org/10.1016/j.rser.2016.05.039

[27] AEMO. (2017). Aemo Average Price Tables. Available: https://www.aemo.com.au/Datasource/Archives/Archiv e769, Date Accessed on 6.9.2017

[28] Lipp J. (2007). Lessons for effective renewable electricity policy from Denmark, Germany and the United Kingdom. Energy Policy 35: 5481-5495. https://doi.org/10.1016/j.enpol.2007.05.015

[29] Pye J, Hughes G, Abbasi E, Asselineau CA, Burgess G, Coventry J, Logie WR, Venn F, Zapata J. (2015). Development of a higher-efficiency tubular cavity receiver for direct steam generation on a dish concentrator. AIP Conference Proceedings 1734: 030029. https://doi.org/10.1063/1.4949081

[30] Poruschi L, Ambrey CL, Smart JCR. (2018). Revisiting feed-in tariffs in Australia: A review. Renewable and Sustainable Energy Reviews 82: 260-270. https://doi.org/10.1016/j.rser.2017.09.027

[31] Turkenburg WC, Arent D, Bertani R, Faaij A, Hand M, Krewitt W. (2012). Global energy assessment-toward a sustainable future. Renewable Energy 761-900.

[32] Haidar AMA, Muttaqi K, Sutanto D. (2015). Smart grid and its future perspectives in Australia. Renewable and Sustainable Energy Reviews 51: 1375-1389. https://doi.org/10.1016/j.rser.2015.07.040 